Supplement of The Cryosphere, 12, 1273-1291, 2018

https://doi.org/10.5194/tc-12-1273-2018-supplement

(C) Author(s) 2018. This work is distributed under

the Creative Commons Attribution 4.0 License.

(c) (1)

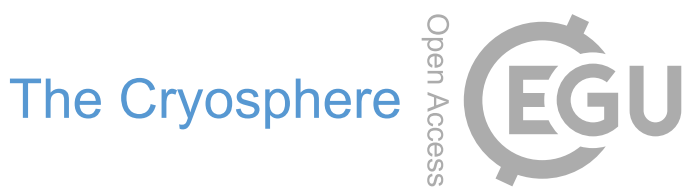

Supplement of

\title{
Changing pattern of ice flow and mass balance for glaciers discharging into the Larsen A and B embayments, Antarctic Peninsula, 2011 to 2016
}

Helmut Rott et al.

Correspondence to: (helmut.rott@enveo.at)

The copyright of individual parts of the supplement might differ from the CC BY 4.0 License. 


\section{Contents}

11 Section S1 - Overview on glacier basins for retrieval of volume change and mass balance

12 The outlines of the glacier basins for retrieval of volume change and mass balance are displayed on a Landsat image for Larsen A and B (Figures S1 and S2). Locations of flux gates and of ice velocity profiles are also shown. For Larsen B glaciers we show locations of ice velocity profiles 1995 to 2013 by Wuite et al. (2015) which are of relevance for the scientific discussion of results presented in the paper. Table S1 contains a list of the basins with area extent in 2013 and 2016 and the GLIMS ID for the main glacier in each basin.

\section{Section S2 - Data coverage by TanDEM-X interferometric SAR data}

A map with area coverage of the TanDEM-X SAR image tracks used for DEM retrieval is shown (Figure S3) and the specifications of the DEMs used for generating surface elevation change (SEC) products are listed (Table S2).

Section S3 - Estimation of uncertainty for surface elevation change and mass budget

Details are presented on the procedures and data base for estimating the uncertainty of the differencing and by the mass budget method.

\section{Section S4 - TerraSAR-X image with ice mélange and sea ice in proglacial fjord}

A TerraSAR-X image is shown in order to illustrate typical patterns of ice mélange and sea ice in proglacial fjords during years of persistent sea ice cover. 


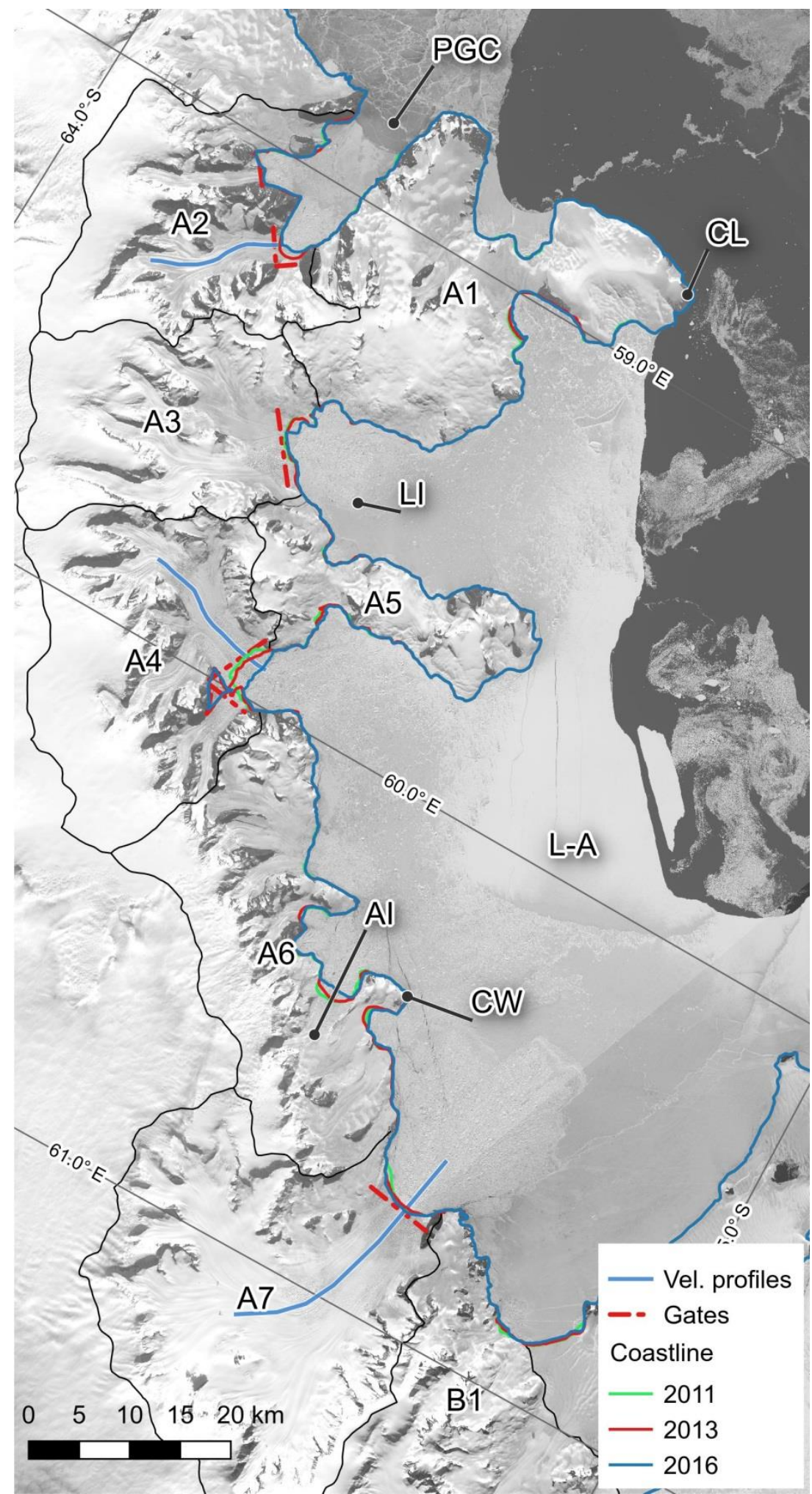

32 Figure S1. Outlines of glacier basins plotted on Landsat image of 2016-10-29. Coastlines 33 from TanDEM-X images mid-2011, -2013, -2016. AI -Arrol Icefall, CW - Cape Worsley, CL34 Cape Longing, L-A - Larsen A embayment, LI - Larsen Inlet, PGC - Prince Gustav Channel Red broken lines: gates for calving fluxes. Blue lines: Ice velocity profiles shown in Fig. 5. 


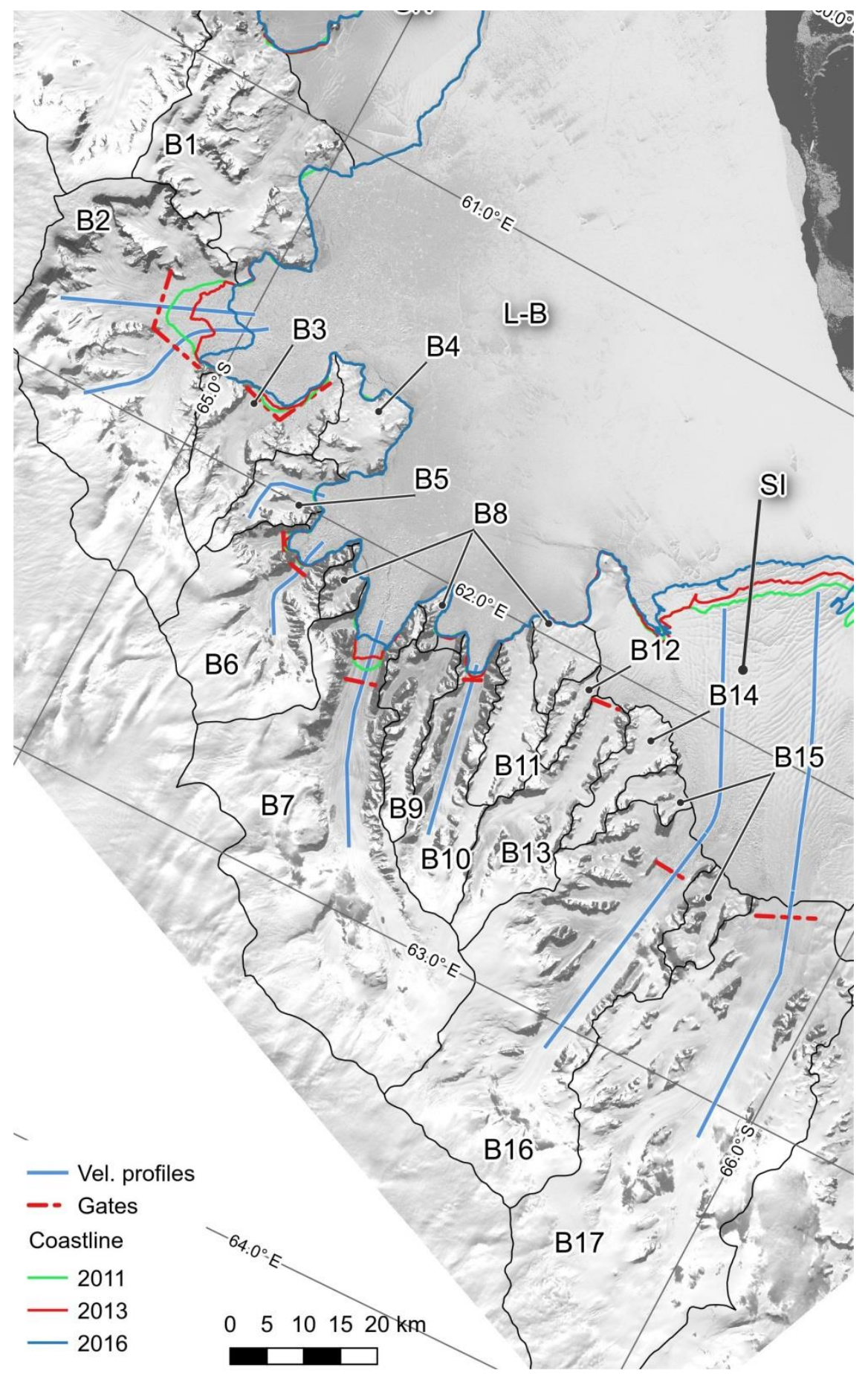

37 Figure S2. Outlines of glacier basins plotted on Landsat image of 2016-10-29. Coastlines

38 from TanDEM-X images mid-2011, -2013, -2016. L-B - Larsen B embayment, SI - SCAR

39 Inlet ice shelf. Red broken lines: gates for calving fluxes. Blue lines: Profiles of ice velocity

401995 to 2013 shown in Wuite et al. (2015). 
42 Table S1. Glacier catchments on northern Antarctic Peninsula (API) for retrieval of surface

43 elevation change (SEC) and mass balance. Basin outlines inland are from the data set of Cook

44 et al. (2014). The position of glacier fronts 2013 and 2016 are from geocoded TerraSAR-X

45 images of June \& July 2013 and July \& August 2016.

\begin{tabular}{|c|c|c|c|c|}
\hline \multirow[t]{2}{*}{ Nr. } & \multirow[t]{2}{*}{ Glacier Basin Name } & \multicolumn{2}{|c|}{ Area $\left[\mathrm{km}^{2}\right]$} & \multirow[t]{2}{*}{ GLIMS ID Nr. (main glaciers of basin) } \\
\hline & & 2013 & 2016 & \\
\hline A1 & Cape Longing Peninsula & 667.30 & 668.91 & G300465E64251S \\
\hline A2 & Sjørgen-Boydell, SB & 525.47 & 527.55 & G300700E64157S \\
\hline A3 & $\begin{array}{l}\text { Albone, Pyke, } \\
\text { Polaris,Eliason, APPE }\end{array}$ & 511.29 & 513.58 & G300465E64251S \\
\hline A4 & $\begin{array}{l}\text { Dinsmoor, Bombardier- } \\
\text { Edgeworth, DBE }\end{array}$ & 646.50 & 653.93 & G299838E64288S \\
\hline A5 & Sobral Peninsula & 256.63 & 257.90 & G300323E64397S \\
\hline A6 & Cape Worsley Coast & 619.39 & 625.07 & G299805E64456S \\
\hline A7 & Drygalski & 998.54 & 998.32 & G298872E64662 \\
\hline B1 & $\begin{array}{l}\text { Six glaciers west of Seal } \\
\text { Nunataks }\end{array}$ & 638.07 & 638.66 & G298833E64908S \\
\hline B2 & Hektoria Green, HG & 1167.49 & 1215.35 & G298013E64919S \\
\hline B3 & Evans & 266.92 & 272.32 & G297915E65081S \\
\hline B4 & Evans Glacier Headland & 117.66 & 117.66 & G298295E65188S \\
\hline B5 & Punchbowl & 119.94 & 119.88 & AQ7LAB000009 \\
\hline B6 & Jorum & 460.33 & 461.41 & G297567E65197S \\
\hline B7 & Crane & 1322.57 & 1333.41 & G297010E65410S \\
\hline B8 & $\begin{array}{l}3 \text { small basins at Larsen } B \\
\text { coast }\end{array}$ & 142.64 & 142.64 & $\begin{array}{c}\text { G297840E65267S, G297936E65370S } \\
\text { G297950E65543S }\end{array}$ \\
\hline B9 & Mapple & 155.43 & 155.43 & G297654E65415S \\
\hline B10 & Melville & 291.47 & 292.91 & G297326E65499S \\
\hline B11 & Pequod & 150.35 & 150.58 & G297685E65521S \\
\hline B12 & Rachel & 51.80 & 51.80 & G297822E65579S \\
\hline B13 & Starbuck & 299.38 & 299.38 & G297312E65606S \\
\hline B14 & Stubb & 108.34 & 108.34 & G297847E65684S \\
\hline B15 & $\begin{array}{l}2 \text { small basins draining to } \\
\text { SCAR Inlet ice shelf }\end{array}$ & 136.78 & 136.78 & G297762E65716S G297484E65849S \\
\hline B16 & Flask & 1130.58 & 1130.58 & G296666E65721S \\
\hline B17 & Leppard & 1851.02 & 1851.02 & G297153E65938S \\
\hline
\end{tabular}


Table S2. Raw DEMs processed as basis for generating SEC products. B6 and B9, respectively $\mathrm{C} 4$ and $\mathrm{C} 7$, include sequential sections of the same swath. Date refers to image acquisition. HoA is height of ambiguity. All images are descending equator crossing / right

51 looking. Incidence angle refers to mid-swath. For spatial coverage see Fig. S.3.

\begin{tabular}{|c|c|c|c|c|c|}
\hline Scene Label & Master / Slave & Date & HoA [m] & Rel. Orbit & $\begin{array}{c}\text { Incidence. } \\
\text { Angle }\end{array}$ \\
\hline A & M & $2013-10-02$ & -174.08 & 34 & 38.4 \\
\hline B6 & M & $2013-07-01$ & -60.64 & 125 & 45.6 \\
\hline B9 & M & $2013-07-01$ & -60.64 & 125 & 45.6 \\
\hline C4 & M & $2013-06-20$ & -56.73 & 125 & 40.6 \\
\hline C7 & M & $2013-06-20$ & -56.73 & 125 & 40.6 \\
\hline D & M & $2013-06-09$ & -53.31 & 125 & 38.4 \\
\hline E & M & $2013-05-18$ & -52.23 & 125 & 36.1 \\
\hline F & M & $2013-07-29$ & -68.93 & 49 & 40.6 \\
\hline A & S & $2016-07-10$ & -27.65 & 34 & 38.4 \\
\hline B6 & S & $2016-08-07$ & -26.64 & 125 & 45.6 \\
\hline B9 & S & $2016-08-07$ & -26.64 & 125 & 45.6 \\
\hline C4 & S & $2016-07-27$ & -29.11 & 125 & 40.6 \\
\hline C7 & S & $2016-07-27$ & -29.11 & 125 & 40.6 \\
\hline D & S & $2016-07-16$ & -27.55 & 125 & 38.4 \\
\hline E & S & $2016-08-18$ & -20.62 & 125 & 36.1 \\
\hline F & S & $2016-07-22$ & -29.69 & 49 & 40.6 \\
\hline 11A & S & $2011-05-06$ & -50.59 & 34 & 37.3 \\
\hline 11B & S & $2011-06-30$ & 51.80 & 34 & 36.1 \\
\hline 11C & S & $2011-06-25$ & 57.62 & 125 & 41.0 \\
\hline
\end{tabular}




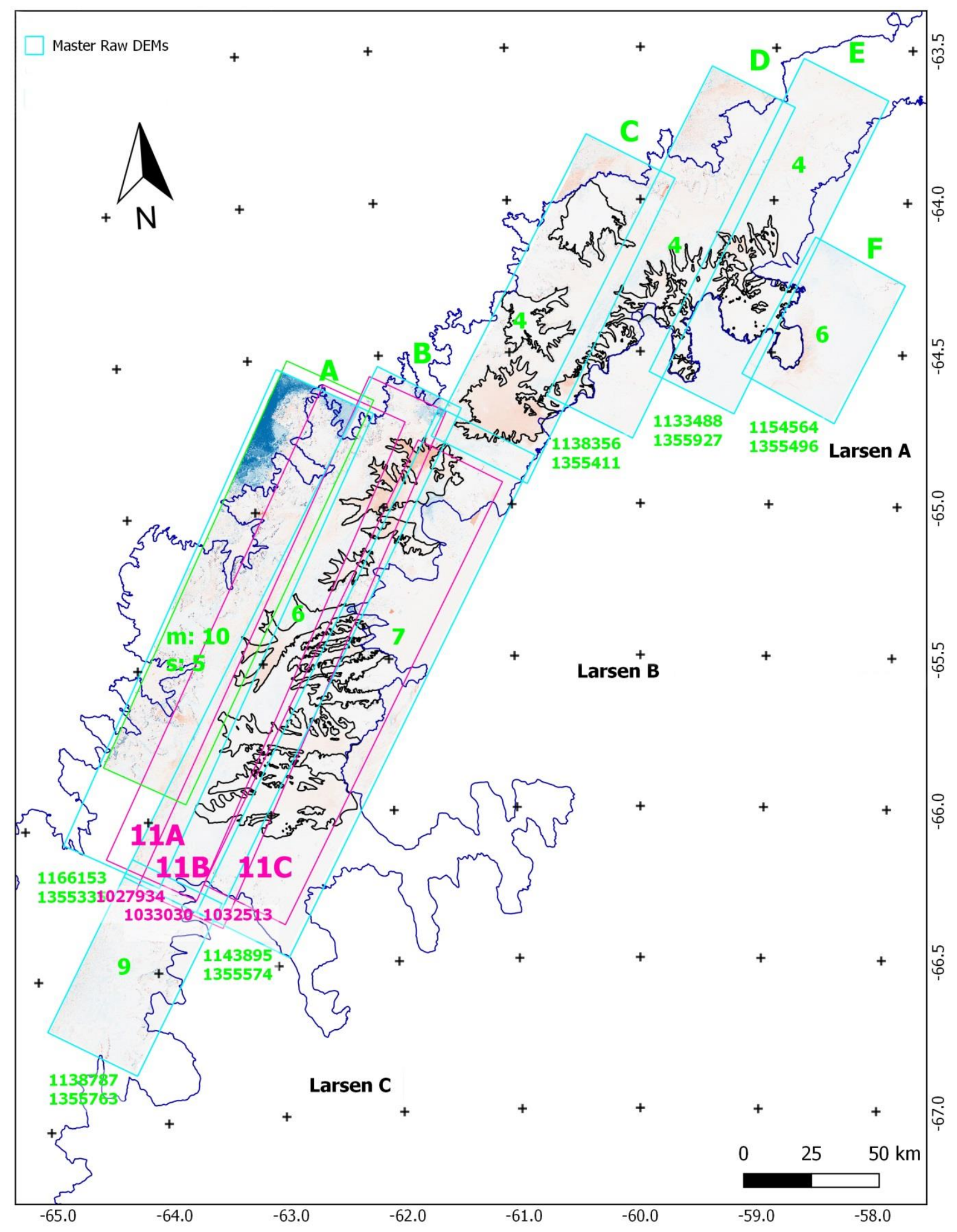

54 Figure S3. Geographic coverage of TanDEM-X tracks for generating DEMs and maps of surface elevation change. Red: tracks for 2011 DEMs. Green: tracks for 2013 to 2016 DEMs. Data specifications in Table S2. 


\section{Section S3 - Estimation of uncertainty for surface elevation change and mass budget}

\section{S3.1 DEM differencing}

For estimating the uncertainty of the TanDEM-X (TDM) elevation change product we compare TDM SEC data over the time span 2011 to 2016 with surface elevation rate of change data (dh/dt, product code IDHDT4) derived from Airborne Topographic Mapper (ATM) swathes, acquired during NASA IceBridge campaigns on 2011-11-14 and 2016-11-10 (Studinger, 2014, updated 2017). Each IDHDT4 data record corresponds to an area where two ATM lidar swathes have co-located measurements. The IDHDT4 data are provided as discrete points representing $250 \mathrm{~m} \times 250 \mathrm{~m}$ surface area and are posted at about $80 \mathrm{~m}$ along-track spacing. We compare mean values of cells comprising 7 x $7 \mathrm{TDM} \mathrm{dh} / \mathrm{dt}$ pixels (of about $12 \mathrm{~m}$ x $12 \mathrm{~m}$ pixel size) with the corresponding IDHDT4 points along flowlines of six glaciers (Table S3). The ATM profiles extend from the ice front (on Leppard Glacier from a position several km up-glacier) up to different altitudes. On Drygalski Glacier and Crane Glacier we start the comparison several $\mathrm{km}$ inland of the front, because the lower sections of the terminus are very crevassed and the ice front positions differed on the dates of the ATM and TDM DEM acquisitions. A small percentage of the ATM dh/dt data shows high RMS (in crevasse zones and on steep slopes); these points are not used for the comparison.

Table S3. Mean rates of elevation change (dh/dt) 2011 to 2016 measured by ATM and TanDEM-X (TDM) for longitudinal profiles on Larsen outlet glaciers. $\Delta\langle\mathrm{dh} / \mathrm{dt}\rangle$ - difference of mean dh/dt (ATM - TDM.) RMSD - root mean square difference.

\begin{tabular}{|l|c|c|c|c|c|}
\hline Glacier & $\begin{array}{c}\mathrm{dh} / \mathrm{dt}\left[\mathrm{m} \mathrm{a}^{-1}\right] \\
\text { ATM 2011-16 }\end{array}$ & $\begin{array}{c}\mathrm{dh} / \mathrm{dt}\left[\mathrm{m} \mathrm{a}^{-1}\right] \\
\text { TDM 2011-16 }\end{array}$ & $\begin{array}{c}\Delta\langle\mathrm{dh} / \mathrm{dt}\rangle \\
{\left[\mathrm{m} \mathrm{a}^{-1}\right]}\end{array}$ & $\begin{array}{c}\text { RMSD } \\
{\left[\mathrm{m} \mathrm{a}^{-1}\right]}\end{array}$ & $\begin{array}{c}\text { Nr. ATM } \\
\text { samples }\end{array}$ \\
\hline Crane & -2.460 & -2.472 & +0.012 & 0.219 & 238 \\
\hline Flask & -1.346 & -1.272 & -0.074 & 0.149 & 172 \\
\hline Leppard & -1.092 & -0.896 & -0.196 & 0.218 & 205 \\
\hline Melville & -1.362 & -1.299 & -0.063 & 0.232 & 165 \\
\hline Starbuck & -0.459 & -0.309 & -0.156 & 0.172 & 41 \\
\hline Drygalski & -4.707 & -4.663 & -0.044 & 0.350 & 92 \\
\hline
\end{tabular}

For the error analysis we assume that the differences result from uncertainties in both data sets. We assume for RMSD $=0.28 \mathrm{~m} \mathrm{a}^{-1}$ (as representative value), resulting in $\mathrm{RMSE}=0.20$ $\mathrm{m} \mathrm{a}^{-1}$ at the scale of individual cells for the each of the two data sets. This number is valid for $\mathrm{a} \mathrm{dh} / \mathrm{dt}$ time span of 1 year, derived from $\Delta \mathrm{h}$ measurements over a time span of 5 years. Measurements for the shorter periods ( 2 years, 3 years) are scaled accordingly. In addition, we 
include uncertainty estimates for a possible bias, with bulk values for the mapped area below the escarpment, the unsurveyed slopes, and the ice plateau.

The following formulation is applied for estimating the uncertainty of volume change, $\mathrm{E}_{\Delta \mathrm{V}}$ $\left[\mathrm{m}^{3} \mathrm{a}^{-1}\right]$, for a glacier basin covering an area $\mathrm{A}_{\mathrm{B}}$ :

$$
E_{\Delta V}=A_{B} \sqrt{f_{m} \frac{S_{e}^{2}}{n}+f_{m} E_{m}^{2}+f_{p} E_{p}^{2}}
$$

The following values are used to obtain annual rates of volume change for the Larsen glacier basins, based on $\Delta \mathrm{h}$ measurements over time spans of 2 years (2011-2013) and 3 years (20132016):

- $\mathrm{S}_{\mathrm{e}}$, random error for the TDM dh/dt map: $\mathrm{S}_{\mathrm{e}}=0.58 \mathrm{~m} \mathrm{a}^{-1}(\Delta \mathrm{h} 2 \mathrm{yr}) ; \mathrm{S}_{\mathrm{e}}=0.39 \mathrm{~m} \mathrm{a}^{-1}(\Delta \mathrm{h}$ $3 \mathrm{yr})$

- $\mathrm{E}_{\mathrm{m}}$, possible bias for TDM dh/dt maps below the escarpment: $\mathrm{E}_{\mathrm{m}}=0.075 \mathrm{~m} \mathrm{a}^{-1}(\Delta \mathrm{h} 2$ $\mathrm{yr}) ; \mathrm{E}_{\mathrm{m}}=0.05 \mathrm{~m} \mathrm{a}^{-1}(\Delta \mathrm{h} 3 \mathrm{yr})$

- $E_{p}$, possible bias for $\mathrm{dh} / \mathrm{dt}$ on ice plateau and on unsurveyed slopes: $E_{p}=0.15 \mathrm{~m} \mathrm{a}^{-1}$ $(\Delta \mathrm{h} 2 \mathrm{yr}) ; \mathrm{E}_{\mathrm{p}}=0.10 \mathrm{~m} \mathrm{a}^{-1}(\Delta \mathrm{h} 3 \mathrm{yr})$

For the first term under the square-root an estimate for the number of statistically independent samples (n) is needed, accounting for spatial correlation. We assume a distance of $500 \mathrm{~m}$ for spatial decorrelation. The second term accounts for a possible bias of the TDM dh/dt maps below the escarpment. The factors $f_{m}$ and $f_{p}$ account for the extent of the respective area relative to the total basin area. The bias estimates for the ice plateau and the unsurveyed slopes are also deduced from the comparison of ATM and TDM dh/dt data. They are based on the first two terms under the square root of Eq. S1, applying $\mathrm{f}_{\mathrm{m}}=1.0, \mathrm{n}=80$, and increasing the resulting value by $50 \%$ to allow for an additional margin.

For converting volume change to mass change we assume a mean density $\rho=900 \mathrm{~kg} \mathrm{~m}^{-3}$. This value is commonly used for geodetic mass balance studies in case the mean density of the snow/ice column does not change. From the similarity of the radar backscatter coefficients in the 2011 and 2016 TanDEM-X images we can exclude significant changes in the structure and density of the snow/firn column. The good agreement between the IceBridge lidar based $\mathrm{dh} / \mathrm{dt}$ values and the TanDEM-X based $\mathrm{dh} / \mathrm{dt}$ values indicates also stability of the structure and density of the snow/ice medium. Changes of density and structure would cause a vertical shift of the radar scattering phase centre within the volume, resulting in a relative shift of the surface in the SAR DEM data versus the surface in the optical data (Dall, 2007). The stability of radar backscatter and the good agreement of optical and radar $\mathrm{dh} / \mathrm{dt}$ indicate that the 
possible error due to density changes in the vertical column is negligible compared to the uncertainty in $\mathrm{dh} / \mathrm{dt}$. Scambos et al. (2014) use also a mean density of $900 \mathrm{~kg} \mathrm{~m}^{-3}$ for converting volume change into mass for their mass balance analysis of glaciers on the northern Antarctic Peninsula over the period 2001 to 2010, so that these mass changes can be directly compared with our estimates.

120 For estimating the uncertainty of sub-regions (Larsen A, Larsen B embayment, SCAR Inlet)

121 we assume that the errors for glaciers covered by a single TDM track are correlated (the errors 122 are added) and the errors of different tracks are uncorrelated.

\section{$123 \quad$ S3.2 Mass budget method}

124 The uncertainty estimate for mass balance at basin scale, derived by means of the mass budget 125 method, accounts for uncertainties of surface mass balance (SMB) and for uncertainties in 126 flow velocity and ice thickness at the flux gates. The SMB is based on output of the regional climate model RACMO Version 2.3p2 (van Wessem et al., 2016; 2017). For the uncertainty of surface mass balance at basin scale we assume $\pm 15 \%$ uncertainty for the average SMB. This value is based on an evaluation of the RACMO SMB output on the Antarctic Peninsula, showing good agreement with the balance flux of Larsen B glaciers in pre-collapse state (van Wessem et al., 2016).

132 The velocities used for computing calving fluxes are exclusively derived from TerraSAR-X 133 and TanDEM-X repeat pass data. The uncertainty in the magnitude of the TerraSAR-X derived surface motion product over Larsen B glaciers at $50 \mathrm{~m}$ grid size is estimated at \pm 0.05 $\mathrm{m} \mathrm{d}^{-1}$ (details in Wuite et al., 2015). Besides, we performed a direct comparison between GPS velocity measurements at five stakes made by British Antarctic Survey (BAS) over annual intervals 2009/2010 and 2011/2012 on Flask Glacier and 2011/2012 on Starbuck Glacier.

138 (GPS data kindly made available by BAS for the ESA project GlacAPI: 139 https://glacapi.enveo.at/). Although the TerraSAR-X measurements cover shorter intervals, the agreement is very good: The differences between GPS and TerraSAR-X velocities at the individual stakes are within $\pm 0.01 \mathrm{~m} \mathrm{~d}^{-1}$; the stake velocities ranging from 0.71 to $0.95 \mathrm{~m} \mathrm{~d}^{-1}$ on Flask Glacier and 0.13 to $0.18 \mathrm{~m} \mathrm{~d}^{-1}$ on Starbuck Glacier. This confirms that an uncertainty estimate of $\pm 0.05 \mathrm{~m} \mathrm{~d}^{-1}$ at $50 \mathrm{~m}$ grid size is a rather conservative estimate for the TerraSAR-X/ TanDEM-X based velocity product. For computing calving fluxes we assume $\pm 5 \%$ uncertainty in velocity across the gate. For uncertainty estimates of mass fluxes we assume \pm

$14610 \%$ error for the cross section area of glaciers with GPR data across or close to the gates and $147 \pm 15 \%$ for glaciers where the ice thickness is deduced from frontal height above flotation 


\section{Section S4 - TerraSAR-X image with ice mélange and sea ice in proglacial fjord}

150 Figure S4 shows typical patterns of ice mélange (a mixture of icebergs and bergy bits, held

151

152 together by sea ice) in the fjord in front of Crane, Jorum and Punchbowl glaciers, and sea ice with a larger iceberg in the wider section of the bay.

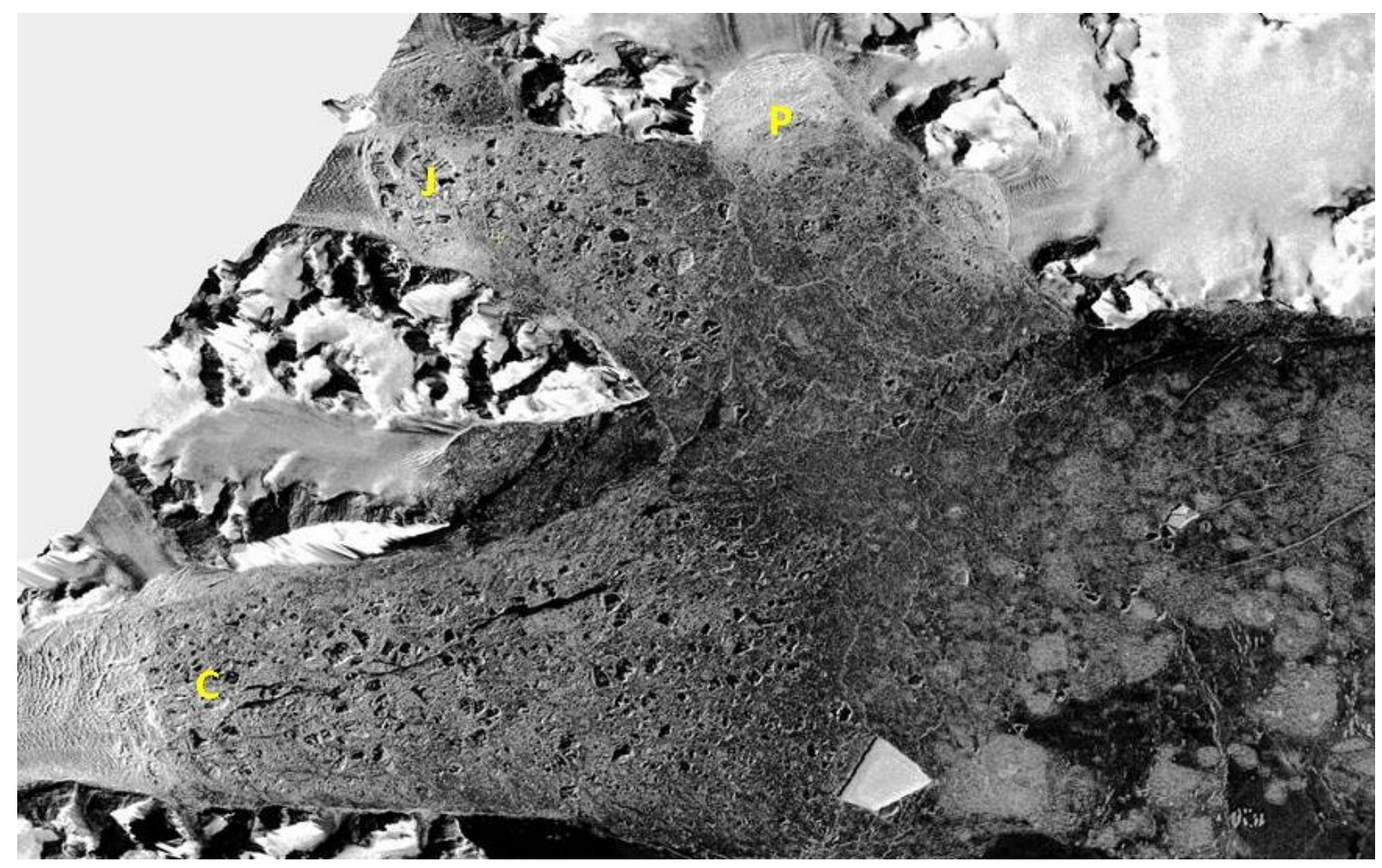

Figure S4. Section of TerraSAR-X amplitude image, acquired on 27 July 2016, with calving fronts of Crane ( C), Jorum (J) and Punchbowl (P) glaciers and the proglacial fjord covered by ice mélange and sea ice.

\section{References}

Cook, A. J., Vaughan, D. G., Luckman, A., and Murray, T.: A new Antarctic Peninsula glacier basin inventory and observed area changes since the 1940s, Antarctic Science, 26(6), 614-624, 2014.

Dall, J.: InSAR elevation bias caused by penetration into uniform volumes. IEEE Trans. Geosc. Remote Sensing, 45(7), 2319-2324, 2007.

Rizzoli, P., Bräutigam, B., Kraus, T., Martone, M., and Krieger, G.: Relative height error analysis of TanDEM-X elevation data, ISPRS J. Photogrammet. Remote Sens., 73, $30-38,2012$.

Scambos, T. A., Berthier, E., Haran, T., Shuman, C. A., Cook, A. J., Ligtenberg, S. R. M., and Bohlander, J.: Detailed ice loss pattern in the northern Antarctic Peninsula: widespread decline driven by ice front retreats, The Cryosphere, 8, 2135-2145, doi:10.5194/tc-8- 
Studinger, M. S: IceBridge ATM L4 Surface Elevation Rate of Change, Version 1, Subset M699, S10, Boulder, Colorado USA. NASA National Snow and Ice Data Center Distributed Active Archive Center, doi: http://dx.doi.org/10.5067/BCW6CI3TXOCY, [Accessed 25 July 2017], 2014, updated 2017.

van Wessem, J. M., Ligtenberg, S. R. M., Reijmer, C. H., van de Berg, W. J., van den Broeke, M. R., Barrand, N. E., Thomas, E. R., Turner, J., Wuite, J., Scambos, T. A., and van Meijgaard, E.: The modelled surface mass balance of the Antarctic Peninsula at 5.5 km horizontal resolution, The Cryosphere, 10, 271-285, 2016.

van Wessem, J. M., van de Berg, W. J., Noël, B. P. Y., van Meijgaard, E., Birnbaum, G., Jakobs, C. L., Krüger, K., Lenaerts, J. T. M., Lhermitte, S., Ligtenberg, S. R. M., Medley, B., Reijmer, C. H., van Tricht, K., Trusel, L. D., van Ulft, L. H., Wouters, B., Wuite, J., and van den Broeke, M. R.: Modelling the climate and surface mass balance of polar ice sheets using RACMO2, part 2: Antarctica (1979-2016), The Cryosphere Discuss., https://doi.org/10.5194/tc-2017-202, in review, 2017.

Wuite, J., Rott, H., Hetzenecker, M., Floricioiu, D., De Rydt, J., Gudmundsson, G. H., Nagler, T., and Kern, M.: Evolution of surface velocities and ice discharge of Larsen B outlet glaciers from 1995 to 2013, The Cryosphere, 9, 957-969, doi:10.5194/tc-9-957-2015, 2015. 